\title{
IMPLEMENTASI DEMOKRASI DALAM PERANAN AHLU AL-HALLI WA AL-`AQDI
}

\author{
Iskandar Syukur \\ Fakultas Dosen Syari'ah UIN Raden Intan Lampung \\ J1 Endro Suratmin Sukarame Bandar Lampung \\ Email: issyukur@yahoo.com
}

\begin{abstract}
This paper discusses the implementation of democracy in the role of $A b l u$ al-Halli $W a$ al-'Aqdi. It is a representative institution (legislative body) of various elements in society and given some authorities to accommodate and carry out people's aspirations; starting from the matter of electing/appointing state leaders until making laws to regulate other matters related to the interests of the state and the people. In setting a case, the Ablu al-Halli Wa al-'Aqdi institution, firstly, must be based on the provisions of Allah SWT and His Prophet and, secondly, based on deliberation in line with the provisions of Allah SWT or according to the spirits/values of Islam/Shari'ah. Ablu al-Halli Wa al-qAqdi's membership consists of people who have great strength both in terms of personality and expertise. However, Muslim scholars differ on the number of members of this institution in the context of electing/appointing state leaders. By discussing the existence of Ablu al-Halli $W a$ al-qAqdi as a representative institution, and it always prioritizes the process of deliberation in deciding all cases that become under its authority, then the existence and role of $A$ hlu al-Halli $W$ a al-qAqdi institution are parts of the democratic process.

Key Words: Demokrasi, Peranan, Ablu al-Halli Wa al-'Aqdi
\end{abstract}

\section{A. Pendahuluan}

Demokrasi terdiri dari dua kata demos (rakyat) dan kratos (kekuasaan atau aturan). Kedua kata tersebut berasal dari bahasa Yunani yang menunjukkan bahwa kekuasaan sebenarnya milik rakyat. Oleh sebab itu, pengertian demokrasi, sebagaimana Abraham Lincoln, Presiden Amerika ke-16, mengatakan, adalah "pemerintahan dari rakyat, oleh rakyat, dan untuk rakyat." Beberapa ahli politik telah memberikan pandangan mereka tentang pengertian demokrasi. Seperti Joseph Schumpeter mengatakan

1 A.A. Said Gatara, Moh. Dzulkiah Said, Sosiologi politike (Bandung: Pustaka Setia, 2007), h. 190. bahwa demokrasi merupakan sebuah sistem dimana individu-individu, dengan kekuasaan yang diberikan oleh rakyat dengan cara bersaing, membuat keputusan-keputusan politik. Marjanne Termorshuizen-Artz mengkaitkan demokrasi dengan rule of law yang mengatakan bahwa demokrasi adalah model prosedur yang sah, dengan memiliki kekuasaan tertentu, sebagai legalitas formal. Bagi Giovani Sartori, demokrasi adalah suatu sistem politik yang di dalamnya terdapat kelompok mayoritas dan kelompok minoritas, yang dipilih dan saling berkompetisi. Kelompok kedua menjamin pengaruh kelompok pertama, dan kepada kedua kelompok tersebut sistem politik disandarkan. Adapun menurut A. Weale, inti makna demokrasi adalah 
pengambilan keputusan oleh warga negara secara bersama-sama dan dalam posisi yang sama. ${ }^{2}$ Menurut Henry B. Mayo, demokrasi adalah sistem politik dimana kebijakan umum ditetapkan oleh suara mayoritas dari wakil-wakil yang dipilih secara efektif oleh rakyat melalui suatu proses pemilihan yang berkelanjutan yang berdasarkan kepada kesamaan politik dan jaminan kebebasan politik ${ }^{3}$

Sedangkan demokrasi menurut pandangan Jimly Asshiddiqie, yang memiliki kesamaan pengertian dengan Abraham Lincoln, bahwa demokrasi merupakan suatu konsep kekuasaan yang berasal dari rakyat, oleh rakyat, dan untuk rakyat. ${ }^{4}$ Pandangan yang demikian menurut Jimly Asshiddiqie mencakup tiga pengertian, yaitu: (1) bahwa suatu pemerintahan yang berasal dari rakyat (government of the people) adalah pemerintah yang diakui (ligimate government) oleh rakyat dan mendapat dukungan dari rakyat. ${ }^{5}$ Pada masa tertentu, pemerintah tersebut harus dapat mempertanggungjawabkan semua kebijakannya kepada rakyat, secara langsung maupun tidak

${ }^{2}$ Anis Ibrahim, Legislasi dalam Perspektif Demokrasi: Analisis Interaksi Politik dan Hukum dalam Proses Pembentukan Peraturan Daerah di Jawa Timur (Universitas Diponegoro: Disertasi, 2008), h. 113-114.

3 Ni'matul Huda, Hukum Tata Negara Indonesia (Jakarta: PT Raja Grafindo Persada, 2010), h. 259.

4 Ibid., Anis Ibrahim, Legislasi dalam Perspektif Demokrasi..., h. 115.

$$
5 \text { Dwi Suliswono, Tri }
$$

Wahyuningsih, Dikdik Baegaqi Arif, Demokrasi (Yogjakarta: Program Studi Pendidikan Kerwarganegaraan, Universitas Ahmad Dahlan), h. 4. langsung, baik yang akan dilaksanakan maupun yang telah dilaksanakan. ${ }^{6}$ (2) Pemerintahan oleh rakyat (government by the people) bahwa suatu pemerintah menjalankan kekuasaan selalu atas nama rakyat bukan atas nama yang lain. Dalam konteks ini, rakyat dapat mengawasi (sosial control) pelaksanaan kekuasaan tersebut secara langsung maupun tidak langsung (seperti melalui Dewan Perwakilan Rakyat/DPR). (3). Pemerintahan untuk rakyat (government for the people) bahwa pemerintah menjalankan kekuasaan untuk kemaslahatan rakyat. ${ }^{7}$

Demokrasi dalam praktiknya memiliki berbagai macam model, di antaranya, adalah model demokrasi langsung (partisipasif) dan model demokrasi tidak langsung (perwakilan). Demokrasi partisipasif adalah suatu sistem dimana warga negara secara langsung terlibat dalam pengambilan keputusan tentang persoalan umum. Sedangkan demokrasi perwakilan adalah suatu sistem dimana rakyat melalui wakil-wakil mereka, yang dipilih berdasarkan wilayah-wilayah tertentu, terlibat dalam pengambilan keputusan dengan menjunjung tinggi hukum yang berlaku. $^{8}$

Untuk menjalankan model demokrasi perwakilan atau demokrasi tidak langsung diperlukan berbagai macam lembaga, di antaranya adalah

6 Muntoha, "Demokrasi dan Negara Hukum," dalam Jurnal Hukum, No. 3, Vol. 16 Juli, 2009: 381.

${ }^{7}$ Dwi Suliswono,_Demokrasi ... , h. 4

8 David Held, Demokrasi dan Tatanan Global dari Negara Modern Hingga Pemerintaban Kosmopolitan (Yogjakarta: Pustaka Pelajar, 2004), h. 5-6 
lembaga perwakilan. Lembaga ini mewakili berbagai macam golongan dan kepentingan yang ada dalam masyarakat, dan keberadaan lembaga ini juga sebagai cerminan dari kedaulatan rakyat. Menurut Jimly Asshiddiqie, apabila dilihat dari struktur lembaga perwakilan, ada tiga prinsip perwakilan yang dikenal di dunia yaitu representasi politik (political representation), representasi teritorial (territorial representation), dan representasi fungsional (functional representation). Representasi politik adalah perwakilan yang dipilih melalui prosedur partai politik sebagai salah satu unsur demokrasi pada masa modern. Representasi teritorial adalah perwakilan yang dipilih berdasarkan daerah. Keberadaan mereka sebagai pihak/kelompok pengimbang (double check) bagi perwakilan partai politik sehingga keduanya saling mengawasi dan saling bekerja sama dalam menampung dan menyalurkan aspirasi dan kepentingan seluruh rakyat. Sedangkan representasi fungsional adalah perwakilan yang dipilih berdasarkan pada keahlian atau profesi tertentu. Dari ketiga prinsip perwakilan di atas, prinsip pertama dan kedua banyak dipakai oleh negara-negara yang bersifat kompleks terutama yang berbentuk federal karena memiliki keseimbangan (double check) yang sepadan. Dalam pelaksaaan kedua prinsip tersebut, negara-negara yang bersangkutan membentuk struktur lembaga perwakilan yang memiliki dua kamar (bicamerab).

9 Syofyan Hadi, "Prinsip Checks And Balances Dalam Struktur Lembaga Perwakilan Rakyat Di Indonesia (Studi Terhadap Usulan Perubahan Kelima UUD NRI Tahun 1945)," dalam Jurnal Ilmu
Ada beberapa istilah yang biasa digunakan untuk menyebut lembaga perwakilan. Antara lain legislature, assembly dan parliament. Istilah legislature menunjukkan bahwa lembaga perwakilan tersebut adalah sebagai lembaga legislatif karena salah satu fungsi utamanya adalah membuat undang-undang (legislasi). Sedangkan istilah assembly menunjukkan bahwa lembaga perwakilan merupakan tempat/sarana/wadah untuk berkumpul dalam hal membahas masalah-masalah negara dan rakyat. Istilah parliament mempunyai pengertian yang hampir sama dengan istilah assembly karena kata parler berarti bicara. Jadi parlemen dapat diartikan juga sebagai tempat bicara, membahas atau merundingkan masalah-masalah kenegaraan. ${ }^{10}$ Menurut Cipto, Amerika Serikat menggunakan istilah legislature, sementara banyak negara-negara Eropa menggunakan istilah parliament atau assembly. ${ }^{11}$ Sedangan dalam politik Islam, lembaga perwakilan dinamakan Ablu al-Halli $W a$ al-'Aqdi. Artikel ini ditujukan untuk membahas keberadaan lembaga Ablu al-Halli $W$ a al-'Aqdi dari konteks demokrasi.

\section{B. Pembahasan}

1. Lembaga Ablu al-Halli $W a$ al'Aqdi

Secara bahasa, Ablu al-Halli $W a$ al-'Aqdi terdiri dari tiga kata. Ablu berarti orang yang memiliki atau

Hukum, Edisi: Januari - Juni, 2014: 50.

${ }^{10}$ Miriam Budiarjo, Dasar-Dasar Ilmu Politik Jakarta: Gramedia Pustaka, 2008), h. 315.

${ }_{11}$ Bambang Cipto, Dewan

Perwakilan Rakyat Dalam Era

Pemerintahan Modern Industrial (Jakarta : Rajawali Press,1995), h. 2. 
orang yang berhak, al-Halli berarti melepaskan, menyesuaikan, memecahkan, dan 'Aqdi berarti mengikat, mengadakan transaksi, membentuk. Jadi Ablu al-Halli $W a$ al-'Aqdi adalah orang-orang yang memiliki hak atau kewenangan untuk menentukan, memecahkan, atau memutuskan suatu masalah, dan keputusan tersebut bersifat mengikat. ${ }^{12}$

Ada beberapa pengertian yang lain. Menurut Abd $\mathrm{Al}$ Hamid Anshori bahwa Abl-al-Hall Wa al'Aqd ialah orang-orang yang memiliki wewenang untuk merumuskan dan memutuskan suatu perkara tentang negara dan rakyat berdasarkan pada prinsip kebersamaan (musyawarah). Sedangkan menurut Abu A'la al Maududi, Ablu al-Halli Wa al-'Aqdi adalah sebuah lembaga perwakilan yang menampung dan menyalurkan aspirasi suatu masyarakat, serta berwenang mengeluarkan ketentuan hukum atau undang-undang terhadap suatu perkara sehingga lembaga ini dikatakan sebagai lembaga legislatif. ${ }^{13}$

Menurut Imam al-Mawardi bahwa Ablu al-Halli $W a$ al-'Aqdi memiliki kesamaan dengan ablu alsyuro, ablu al-jibad dan ablu al-ikbtiyar. Memiliki persamaan dengan dengan Abl al-ikbtiyar, bagi Imam alMawardi, karena salah satu wewenang atau hak Ablu al-Halli $W a$

${ }^{12}$ Muhammad Iqbal, Fiqib Siyasah Kontekstualisasi Doktrin Politik Islam (Jakarta: Gaya Media Pratama, 2007), h. 138.

${ }^{13}$ Abul A'la Al-Maududi, Hukum dan Konstitusi: Sistem Politik Islam, diterjemahkan oleh Asep Hikmat (Bandung: Mizan, 1990), h. 245.
al-'Aqdi adalah memilih pemimpin negara atas nama hak pilih yang dimiliki oleh rakyat. Selanjutnya, memiliki kesamaan dengan ablu alsyuro karena, bagi Imam al-Mawardi, Ablu al-Halli $W a$ al-'Aqdi dalam membuat segala keputusan harus melalui musyawarah. Sedangkan bagi Ibnu Taymiyah Ablu al-Halli Wa al-'Aqdi memiliki kesamaan dengan abl al-Syaukah, sebagian lagi menyamakan dengan abl al-ijma'. Sementara al- Baghdadi menamakan Ablu al-Halli $W$ a al-'Aqdi dengan abl al-Ijtibad. $^{14}$

Dengan demikian, Ablu al-Halli $W a$ al-'Aqdi adalah lembaga perwakilan (lembaga legislatif) yang beranggota sebagai representasi dari seluruh unsur dalam masyarakat dan diberi kewenangan untuk menampung dan melaksanakan aspirasi masyarakat, dalam hal memilih pemimpin negara, membuat undang-undang, dan lainlain.

2. Keanggotaan Lembaga Ablu alHalli Wa al-'Aqdi

Dalam pembahasan terhadap keanggotaan Ablu al-Halli $W a$ al'Aqdi beberapa ahli politik Islam telah memberikan pandangan mereka masing-masing. Rosyid Ridha berpandapat bahwa keanggotaan lembaga ini adalah terdiri dari orang-orang yang telah mendapatkan kepercayaan dari umat baik itu dari kalangan ulama yang telah berstatus mujtahid, maupun dari kalangan tokoh-tokoh lain seperti para pemimpin militer, para pemimpin pekerja, para pemimpin

\footnotetext{
${ }^{14}$ Muhammad Iqbal, Fiqih Siyasah Kontekstualisasi ...., h. 138.
} 
perusahaan. ${ }^{15}$ Menurut Muhammad Abduh, keanggotaan Ablul Halli $W$ al 'Aqdi terdiri dari orang-orang yang memiliki keahlian baik dalam bidang agama maupun dalam bidangbidang lainnya, keahlian mereka masing-masing sudah melalui proses pengujian, dan menjadi rujukan oleh umat Islam dalam masalah publik. Selain itu, mereka bagi Muhammad Abduh tidak melanggar ketentuan Allah dan Sunnah Rasul yang berderajat mutawatir. Mereka itu adalah para amir, para hakim, para ulama, para militer, dan para pemimpin lainnya. ${ }^{16}$

Keanggotaan Abl al-Halli wa al 'Aqdi menurut An-Nawawi terdiri dari para ulama, para pemimpin, dan para tokoh masyarakat, dari berbagai macam unsur dalam masyarakat, yang telah memiliki hasil karya mereka dalam hal mewujudkan kepentingan atau kemaslahatan masyarakat. Bagi Ibnu Taimiyah keanggotaan Ablu al-Halli $W a$ al'Aqdi terdiri dari orang-orang terpilih karena keahlian tertentu, mereka juga telah memenuhi syaratsyarat kepribadian seperti keberanian, kekuatan, pengetahuan dan akal sehat. Syarat-syarat tersebut dirasakan penting bagi Ibnu Taymiyah karena sikap kebanyakan masyarakat cenderung meniru sikap para pemimpin mereka, oleh karena itu dengan syarat-syarat kepribadian di atas diharapkan para pemimpin dapat memberikan sikap yang baik. ${ }^{17}$

${ }^{15}$ Muhammad Zulifan, "Politik Indonesia," dalam Indonesian Political Science Review, 1, 2, 2016: 178.

${ }^{16}$ Muhammad Iqbal, Fiqh Siyasah Kontekstualisasi...., h. 138.

${ }^{17}$ Khalid Ibrahim Jindan, Teori Politik Islam: Telaah Kritis Ibnu
Para ulama berbeda pendapat mengenai jumlah keanggotaan Ablu al-Halli $W$ a al-'Aqdi, terutama yang berhubungan dengan pengangkatan pemimpin negara. Perbedaan pendapat ini menjadi isu pokok karena sah atau tidaknya suatu pengangkatan seorang pemimpin negara oleh lembaga Abl al-Halli wa al 'Aqdi sangat tergantung kepada jumlah mereka. Sekelompok ulama berpendapat bahwa sahnya suatu pemilihan/pengangkatan seorang pemimpin negara oleh lembaga $A b l$ al-Halli wa al 'Aqdi jika seluruh anggotanya hadir. Pendapat ini berdasarkan kepada sejarah politik Islam ketika Nabi Muhammad SAW telah wafat, pucuk pimpinan negara kemudian diamanatkan kepada Abu Bakar ra yang dipilih/diangkat oleh orang-orang yang hadir dalam majlis musyawarah ketika itu. ${ }^{18}$

Kelompok ulama lain, sebagian besar para fuqaha dan para mutakallimun yang berada di Basrah berpendapat bahwa keanggotan $A b l$ al-Halli wa al 'Aqdi berjumlah minimal lima orang anggota dalam memilih/mengangkat pemimpin negara. Kemudian mereka sepakat bahwa pemimpin negara yang mereka pilih/angkat berasal dari orang lain atau dari salah satu dari kelima anggota tersebut. Pendapat ini bersandarkan kepada dua alasan. Alasan pertama, sebagaimana telah dijelaskan di atas bahwa Abu Bakar

Taimiyyah tentang Pemerintaban Islam, diterjemahkan oleh Masrinin (Jakarta: Risalah Gusti,1995), h. 24, 63.

18 Muhammad Amin, "Pemikiran Politik Al-Mawardi," dalam Jurnal Politik Profetik, Vol. 04, No. 2, 2016: 126. 
ra diamanatkan sebagai pucuk pimpinan negara setelah dipilih/diangkat oleh orang-orang yang hadir dalam majlis musyawarah ketika itu. Orang-orang yang hadir dalam musyawarah tersebut berjumlah lima orang, yaitu Umar bin Khaththab, Abu Ubaidah bin Al-Jarrah, Usaid bin Hudhair, Bisyr bin Sa'ad, dan Salim bekas budak Abu Hudzaifah. Alasan kedua bahwa ketika Umar bin Khattab membentuk lembaga Ablu alSyuro/Ablu al-Halli $W a$ al-'Aqdi, anggota yang duduk dalam lembaga tersebut sebagai tim formatur berjumlah enam orang. Mereka diperbolehkan memilih/mengangkat seorang pemimpin negara berasal dari salah satu dari keenam anggota tersebut jika kelima anggota yang lain setuju. Namun menurut pandangan Al-Mawardi bahwa enam orang yang duduk dalam lembaga Ablu al-Syuro/Ablu al-Halli $W a$ al'Aqdi sebagai tim formatur, satu di antara mereka berstatus sebagai pihak independen, hanya sebagai penasihat dan tidak memiliki hak untuk memilih ataupun mengangkat. ${ }^{19}$

Para ulama di Kufah berpendapat bahwa Ablu al-Halli $W a$ al-'Aqdi dianggap sah dalam memilih/mengangkat seorang menjadi pemimpin negara dengan beranggotakan tiga orang. Bahkan ketiga anggota tersebut diperbolehkan memilih/mengangkat salah satu dari mereka menjadi pemimpin negara dengan persetujuan kedua anggota yang lain. Para ulama dengan pendapat ini mengambil qiyas dari sah atau tidaknya suatu aqad nikah. Aqad

${ }^{19}$ Ibid. nikah dianggap sah jika dihadiri oleh tiga orang, yaitu satu orang sebagai wali dan dua orang sebagai saksi. Sementara kelompok lain berpendapat bahwa satu orang pun cukup untuk memilih/mengangkat seorang pemimpin negara. Pendapat ini berdasarkan kepada suatu riwayat bahwa Abbas bin Abdul Muthalib ra, telah membait Ali bin Abu Thalib ra sebagai khalifah setelah kematian Utsman bin Affan. Abbas bin Abdul Muthalib ra merupakan paman Nabi dan juga paman Ali bin Abu Thalib ra. ${ }^{20}$

3. Syarat-Syarat Menjadi Anggota Lembaga Ablu al-Halli Wa al'Aqdi

Beberapa ahli politik Islam telah memberikan syarat-syarat menjadi anggota lembaga Ablu al-Halli $W a$ al-'Aqdi. Al-Mawardi telah merumuskan beberapa syarat bahwa anggota lembaga ini harus (1) berlaku adil dalam segala sikap dan tindakan, (2) berilmu pengetahuan, (3) dan memiliki wawasan dan (4) bersikap arif/bijaksana. Syarat-syarat tersebut, bagi Al-Mawardi, termasuk Rasyid Ridha, dapat menjadikan lembaga ini bermartabat dan dapat menentukan/memilih/mengangkat seseorang yang pantas untuk tampil menjadi pemimpin negara sehingga dapat menjalankan urusan negara dan rakyat dengan baik. ${ }^{21}$ Para fuqaha berpendapat bahwa syaratsyarat untuk menjadi anggota lembaga Ablu al-Halli $W$ a al-'Aqdi, antara lain: (1) bersikap adil, (2)

\footnotetext{
${ }^{20}$ Ibid., h. 127

${ }^{21}$ Imam Al-Mawardi, Al-abkam As-sulthaniyyab: Hukum-bukum Penyelenggaraan Negara dalam Syariat Islam ( Jakarta: Darul Falah, 2006), h. 6
} 
mempunyai ilmu pengetahuan, (3) dan memiliki keahlian tertentu. Kedua pendapat di atas pada prinsipnya memiliki kesamaan. Keduanya mengedepankan sikap adil yang menunjukkan bahwa keadilan itu merupakan nilai pokok dalam berhubungan antara manusia dalam berbangsa dan negara. Bahkan pada masa kini keadilan selalu dijunjung tinggi dalam undang-undang negara modern baik bagi pemerintah maupun bagi anggota parlemen.

Selain itu, Ibnu khaldun juga telah memberikan syarat-syarat bagi anggota lembaga Ablu al-Halli Wa al-'Aqdi yaitu (1) mampu melaksanakan tugas, (2) bersikap arif/ bijaksana, (3) memiliki jasmani yang sehat, dan tidak memiliki panca indera dan anggota tubuh yang lain cacat. Sementara ahli politik Islam yang lain memberikan syarat-syarat yang lain sebagai berikut. (1) Memiliki aqidah yang benar, (2) taat dan tekun dalam menjalankan ibadah, (3) berakhlak mulia; sederhanan, amanah dan jujur (4) memiliki sikap yang tegar dan teguh dalam prinsip, (5) berkorban untuk kemajuan Islam, (6) memiliki lmu pengetahuan dalam syariat Islam, (7) memiliki keahlian dan kecakapan dalam bidang tertentu selain syariat Islam. $^{22}$

Setelah membahas tentang syarat-syarat di atas, dapat disimpulkan bahwa siapa-siapa yang duduk sebagai anggota lembaga Ablu al-Halli $W a$ al-'Aqdi adalah orang-orang yang hebat baik dari segi kepribadian, keagamaan

22 Farid Abdul Kholiq, Fikih Politik, (Jakarta: Sinar Grafika, 2005), h. 109-113. maupun dari segi keahlian. Posisi mereka sebagai perwakilan dari berbagai macam unsur dalam masyarakat. Namun bagaimana mereka dipilih, apakah dipilih secara langsung oleh rakyat atau ditunjuk oleh kepala pemerintahan, belum begitu jelas dalam berbagai literatur politik Islam. tetapi dalam sejarah politik Islam, Nabi Muhammad SAW pernah memberikan contoh pemilihan perwakilan secara demokratis. Diceritakan bahwa pada masa Nabi di madinah suku Aus dan Khazraj belum memiliki perwakilan dalam negara madinah sedangkan mereka, setelah Piagam Madinah dibuat, masuk ke dalam kaum anshor. Oleh sebab itu Nabi meminta kepada kedua suku tersebut untuk menentukan siapasiapa yang pantas untuk mewakili mereka. Kemudian kedua suku tersebut secara masing-masing mengadakan pemilihan yang akhirnya ada tiga orang yang mewakili suku Aus dan sembilan orang yang mewakili suku Khazraj. ${ }^{23}$

4. Wewenang Lembaga Ablu al-Halli Wa al-Aqdi

Wewenang secara umum dari lembaga Ablu al-Halli $W a$ al-Aqdi, menurut Al-Mawardi, dapat meliputi dua hal, yaitu (1) mengajak kepada kebaikan dengan cara menetapkan keputusan, kebijakan dan peraturan atau hukum untuk kemaslahatan bersama melalui proses musyawarah. Segala keputusan yang diambil, menurut Ibnu Mufith, diharapkan dapat mencerminkan aspirasi masyarakat atau juga dapat mengurangi atau menghilangkan

${ }^{23}$ J. Suyuthi Pulungan, Fiqh Siyasah (Jakarta: Raja Grafindo, 1997), h. 70. 
pertentangan/konflik yang terjadi atau yang sedang dihadapi oleh masyarakat yang berkenaan. ${ }^{24}$ (2) Menindak, dari tahap teguran sampai ke tahap pemberhentian, para penguasa yang melanggar ketentuan yang berlaku setelah ada bukti-bukti yang telah terpenuhi dan setelah dilakukan musyawarah bersama. ${ }^{25}$

Adapun menurut para ahli ushul fiqh bahwa wewenang lembaga alHalli $W a$ al-Aqdi adalah memilih/mengangkat pemimpin negara dan memberhentikannya, sesuai dengan peraturan yang berlaku, setelah diadakan musyawarah bersama. (2) Mengatur urusan-urusan publik dan membuat serta menetapkan undang-undang, yang tidak bertentangan dengan syariat Islam, untuk kemaslahatan negara dan rakyat. (3) Mengawasi pemerintah dalam penyelenggaraan kenegaraan untuk mencegah mereka dari tindakan pelanggaran terhadap peraturan yang berlaku. ${ }^{26}$

Sejauh yang dikaji dapat disimpulkan bahwa wewenang lembaga abl al-hall wal-'aqdi ini adalah sebagai berikut. (1) Dikatakan sebelumnya bahwa wewenang lembaga Ablu al-Halli $W a$ al-Aqdi adalah memilih/mengangkat pemimpin negara dan memberhentikannya. Dengan demikian, Ablu al-Halli $W a$ al-Aqdi adalah sebagai lembaga yang memegang kekuasaan tertinggi. (2)

${ }^{24}$ Chozin H. Dahlan, "Islam, Politik dan Demokrasi," dalam Jurnal Publiciana, Vol 8, No 1, 2015: 99.

25 Farid Abdul Khaliq, Fikih Politik, h. 87.

${ }^{26}$ Ibid., h. 80 .
Mengajak atau mengarahkan semua komponen masyarakat baik sebagai rakyat biasa maupun sebagai penguasa ke arah kehidupan yang lebih baik. (3) Menetapkan keputusan, kebijakan, peraturan, hukum, undang-undang, yang tidak bertentangan dengan syariat Islam, untuk kemaslahatan negara dan rakyat melalui proses musyawarah. Segala keputusan yang diambil diharapkan dapat mencerminkan aspirasi masyarakat atau juga dapat mengurangi atau menghilangkan pertentangan/konflik yang terjadi atau yang sedang dihadapi oleh masyarakat. (4) Ablu al-Halli Wa alAqdi sebagai lembaga pengawas terhadap dan konsultasi bagi pemerintah (pemimpin negara) di dalam menentukan atau menjalankan kebijakan.

Dalam menjalankan wewenang yang termaktub dalam pont 1 yaitu memilih/mengangkat pemimpin negara, Al-Mawardi berpendapat bahwa pemilihan/pengangkatan pemimpin negara harus memenuhi dua unsur. Unsur pertama adalah adanya para anggota Ablu al-Halli $W$ a al-Aqdi (a) yang telah memenuhi syarat-syarat tertentu, sebagaimana yang telah dihuraikan di atas, dan (b) mengetahui dengan baik calon pemimpin negara baik dari kepribadiannya maupun dari segi kecakapannya. Unsur kedua adalah orang yang akan dipilih/diangkat untuk menduduki jabatan sebagai pemimpin negara. Calon pemimpin negara tersebut, menurut AlMawardi, harus memenuhi syaratsyarat sebagai berikut, yaitu: adil, memiliki kemampuan untuk berijtihad, memililki jasmani yang sehat termasuk panca indera, mempunyai kemampuan 
menjalankan pemerintahan, memiliki keberanian melindungi rakyat dan wilayah kekuasaan dari serangan musuh. ${ }^{27}$

Dalam menjalankan wewenang lembaga yang termaktub dalam pont 3 yaitu membuat hukum atau undang-undang, lembaga Ablu alHalli $W a$ al-Aqdi harus memiliki batasan yang tidak boleh bertentangan dengan apa-apa yang telah ditetapkan oleh Allah dan Rasul-Nya. Dengan kata lain, semua bentuk legislasi yang ditetapkan harus mencerminkan semangat atau jiwa dari ketentuan al-Quran dan alHadist. Dalam konteks ini, AlMaududi telah memberikan pedoman, kurang lebih, sebagai berikut. (1) Jika lembaga Ablu alHalli $W$ a al-Aqdi dalam menetapkan peraturan/undang-undang terhadap satu perkara, sedangkan ada ketentuan yang jelas dari al-Quran dan al-Hadist terhadap perkara tersebut, maka lembaga ini hanya menegakkan ketentuan itu dalam peraturan atau undang-undang. (2) Jika didapati beberapa penafsiran terhadap ketentuan yang jelas dari al-Quran dan al-Hadits terhadap perkara yang sedang dibahas, maka lembaga ini memilih/menetapkan satu dari beberapa penafsiran yang ada, setelah itu merumuskannya ke dalam peraturan atau undangundang. (3) Jika tidak didapati ketentuan dari Al-Quran dan alHadist terhadap perkara yang sedang dibahas, namun ada dalam kitab-kitab fikih/pandangan para

27 Rashda Diana, Siswanto Masruri, Surwandono, "Etika Politik dalam Perspektif al-Mawardi," dalam Tsaqafah, Vol. 14, No. 2, November 2018: 377. ulama mazhab, maka lembaga ini harus mengambil satu dari pandangan-pandangan yang ada, kemudian merumuskannya ke dalam peraturan atau undang-undang. (4) Jika tidak ada ketentuan dari sumber-sumber disebutkan di atas, maka lembaga ini dibebaskan untuk dapat menemukan ketentuan sendiri dengan syarat tidak bertentangan dengan jiwa/nilai/semangat Islam/syari'at. ${ }^{28}$

Dalam menjalankan wewenang yang termaktub dalam pont 4 yaitu sebagai lembaga pengawas dan konsultasi bagi pemerintah (pemimpin negara) di dalam menentukan atau menjalankan kebijakan, lembaga Ablu al-Halli $W a$ al-Aqdi memiliki peran, antara lain, sebagai berikut. (1) Memberikan masukan yang bersifat mengikat kepada pemimpin negara dalam berbagai masalah praktis dalam penyelenggaraan pemerintahan seperti masalah pendidikan, kesehatan, ekonomi, perdagangan, industri, pertanian. (2) Memberikan masukan yang bersifat tidak mengikat kepada pemimpin negara terutama yang berkaitan dengan masalah yang memerlukan penelitian dan analisa. (3) Menerima rencana undang-undang/hukum yang dibuat oleh pemimpin negara untuk dievaluasi dan diberi penilaian meskipun tidak bersifat mengikat. (4) Majelis mempunyai hak untuk mengawasi dan mengevaluasi semua tindakan yang dilakukan oleh

${ }^{28}$ Muhammad Iqbal dan Amien Husein Nasution, Pemikiran Politik. Islam (Jakarta: Prenada Media Group, 2010), h. 184-185. 
pemimpin negara dalam menjalankan pemerintahan...

Sebagai catatan, hasil evaluasi itu dapat saja bersifat mengikat jika evaluasi itu dilakukan oleh anggota lembaga Ablu al-Halli $W a$ al-Aqdi secara konsensus. Tetapi sebaliknya, jika evaluasi itu tidak dilakukan secara konsensus, maka hasil evaluasi tersebut tidak mengikat. Peran lembaga Ablu al-Halli $W a$ alAqdi selanjutnya adalah mengadakan musyawarh bersama antara anggota lembaga Ablu al-Halli $W a$ al-Aqdi dan pemimpin negara jika didapati selisih pendapat antara keduanya terhadap masalah tertentu yang berdasarkan hukum syara', maka keputusan yang diambil bersifat mengikat untuk keduanya. (6) Memberikan masukan kepada pemimpin negara untuk dapat menindak, dari tahap teguran sampai ke tahap pemberhentian, para pejabat dan pegawai pemerintah karena tindakan/sikap mereka tidak sesuai dengan ketentuan yang berlaku. Tetapi masukan tersebut tidak bersifat mengikat karena hal itu merupakan wewenang dari lembaga peradilan (wilayatu al-madzalim) yang berhak mengadili para pejabat dan pegawai pemerintah. (7) Lembaga Ablu alHalli Wa al-Aqdi juga memiliki hak untuk membatasi jumlah calon pemimpin negara yang akan dipilih/diangkat. (8) Lembaga Ablu al-Halli $W$ a al-Aqdi memiliki hak interpelasi, hak angket dan hak menyatakan pendapat. Hak interpelasi yaitu hak untuk meminta keterangan kepada pemimpin negara

29 Munawir Sadjali, Islam Dan Tata Negara (Jakarta : UI-Press, 1993), h. 64- 65. mengenai kebijakan-kebijakan strategis atas dasar pertimbangan kemaslahatan masyarakat, pertimbangan peraturan yang berlaku, dan/atau pertimbangan syari'at Islam. Sedangkan hak angket yaitu hak melakukan penyeledikan terhadap berbagai kebijakan pemimpin negara yang dirasakan bertentangan dengan kemaslahatan masyarakat, peraturan yang berlaku, atau syari'at Islam. ${ }^{30}$

5. Pengambilan Keputusan Oleh Lembaga Ablu al-Halli $W a$ al'Aqdi

Sebagaimana dijelaskan diatas bahwa Abl-al-Hall $W a$ al-'Aqdi sebagai lembaga yang memiliki beberapa wewenang, di antaranaya adalah menetapkan keputusan, kebijakan, peraturan, hukum, undang-undang, yang tidak bertentangan dengan syariat Islam, untuk kemaslahatan negara dan rakyat melalui proses musyawarah. Sehingga lembaga Abl-al-Hall $W$ a al'Aqdi bagi sebagian ahli politik Islam, sebagaimana dijelaskan sebelum ini, menyamakannya dengan ablu al-syuro, ablul jibad dan ablul ak-ikbtiyar, abl al-Syaukah, abl al-Ijma'. Dianggap memiliki kesamaan dengan ablu al-syuro karena Abl-al-Hall Wa al-'Aqdi dalam membuat segala keputusan melalui musyawarah. Menurut Nurcholis Madjid, musyawarah merupakan sarana untuk membentuk sikap dewasa; menerima bentuk-bentuk kompromi dalam mengemukakan pendapat, mendengarkan pendapat orang lain, menerima perbedaan pendapat, dan kemungkinan mengambil pendapat yang lebih baik. Selain itu, musyawarh juga

${ }^{30}$ Ibid. 
dapat menimbul kesadaran pribadi atau kelompok atas keberagaman, dan kesepakatan yang jujur atas pertimbangan moral dan kerjasama. $^{31}$

Menurut Fazlur Rahman, musyawarah (syura) merupakan suatu tradisi yang telah mengakar pada bangsa Arab. Sebelum Islam, tradisi musyawarah sudah dilakukan oleh para pemuka suku atau kota dalam memecahkan suatu urusan/perkara. Setelah Islam datang, tradisi msyawarah ini tetap berlanjut, bahkan Al-Qur'an telah menegaskan dengan cara menyuruh Nabi, sebagaimana tercantum dalam surat Ali Imron: 159 dan dalam surat As-Syura: 38, untuk mengadakan musyawarah secara berkelanjutan dengan orang-orang Islam tentang semua perkara/urusan/masalah yang penting, dan Al-Qur'an juga telah menegaskan bahwa memecahkan semua persoalan melalui proses musyawarah merupakan tindakan yang terhormat. ${ }^{32}$

31 Tim ICCE UIN Jakarta, Pendidikan Kewarganegaraan (Civic Education): Demokrasi, Hak Asasi Manusia dan Masyarakat Madani (Jakarta: Prenada Media, 2005), h. 113-11.

32 Surat Ali Imron, ayat 159: "Maka disebabkan rahmat dari Allah lah kamu berlaku lemah lembut terhadap mereka. Sekiranya kamu bersikap keras lagi berhati kasar, tentulah mereka menjauhkan diri dari sekelilingmu. Karena itu maafkanlah mereka, mohonkanlah ampun bagi mereka, dan bermusyawarahlah dengan mereka dalam urusan itu. Kemudian apabila kamu telah membulatkan tekad,
Contoh cerita/riwayat di bawah ini menunjukkan bagaimana tradisi musyawarah telah dilakukan pada masa awal Islam. Beberapa hari sebelum perang Badar terjadi, merupakan perang pertama antara kaum muslimin dan kaum musyrik pada tahun ke-2 H/624 M, Nabi mengadakan musyawarah dengan (beberapa perwakilan dari) kaum Muhajirin dan Anshor dalam beberapa hal seperti masalah peralatan perang, dan masalah jumlah pasukan Islam yang masih berjumlah relatif sedikit. Ketika menjelang pertempuran terjadi, Nabi telah menetapkan/memutuskan untuk menempatkan posisi pasukan Islam di suatu tempat dekat dengan mata air di Badar. ${ }^{33}$ Di antara pasukan Islam, ada seorang yang bernama Hubab al Mundzir dari kaum Anshor datang dan mendekatkan diri kepada Nabi dengan mengajukan pendapatnya tentang posisi pasukan Islam yang telah ditetapkan oleh Nabi. Menurut Hubab al Mundzir, keputusan Nabi tersebut kuranglah tepat dan mengusulkan bahwa posisi pasukan Islam sebaiknya maju lebih dekat ke

maka bertawakkallah kepada Allah. Sesungguhnya Allah menyukai orang-orang yang bertawakkal kepada-Nya." Surat As-Syura, ayat 38: "Dan (bagi) orang-orang yang menerima (mematuhi) seruan Tuhannya dan mendirikan shalat, sedang urusan mereka (diputuskan) dengan musyawarah antara mereka; dan mereka menafkahkan sebagian dari rezki yang kami berikan kepada mereka."

${ }^{33}$ J. Suyuthi Pulungan, Figh


mata air ketimbang posisi pasukan musuh yang lebih dekat. Tujuan dari usulannya tersebut adalah supaya pasukan Islam dapat mengisi kantong-kantong air dari mata air tersebut kemudian ditimbun dalam pasir sehingga mereka masih dapat minum walaupun dalam keadaan perang, sedangkan pasukan musuh sulit untuk bisa mimum. Mendengar usulan tersebut, Nabi setuju kemudian menempatkan pasukan Islam pada posisi sesuai dengan yang dimaksud oleh Hubab. ${ }^{34}$

'Tradisi musyawarah masih berlanjut pada masa Khulafa alRasyidin, yang pelaksanaannya tidak jauh berbeda dengan masa Nabi. Fazlur Rahman memberikan contoh pidato pelantikan Abu Bakar ra (bai'at) sebagai khalifah pertama dengan menyatakan bahwa dirinya telah menerima mandat dari rakyat sebagai seorang khalifah dan rakyat pula meminta kepada dirinya untuk melaksanakan mandat tersebut sebagai amanah yang sesuai dengan ketentuan al-Qur'an dan al-Sunah. Oleh sebab itu, beliau meminta kepada rakyat untuk mendukungnya secara berkelanjutan. Jika dalam menjalankan amanah tersebut, ia melakukan pelanggaran yang dianggap serius/berat, maka ia siap dan bersedia untuk diturunkan/diberhentikan sebagai khalifah. Selanjutnya, tradisi musyawarah masih berjalan pada masa pemerintahan Umar bin Khattab. Beliau membentuk lembaga Ablu al-Syuro/Ablu al-Halli $W a$ al-'Aqdi dengan beberapa anggota sebagai tim formatur untuk, sebagai salah satu wewenang mereka, memilih/mengangkat seorang khalifah yang baru jika khalifah yang lama telah meninggal dunia. $^{35}$

Jadi dapat disimpulkan bahwa dalam menetapkan sesuatu perkara lembaga Ablu al-Halli $W a$ al-'Aqdi selalu melalui musyawarah sebagai salah satu tradisi yang telah mengakar dalam sejarah politik Islam. Tentunya keputusan mereka harus sejalan dengan ketentuan Allah SWT dan Nabi-nya, atau sesuai dangan jiwa/nilai/semangat Islam/syari'at.

\section{Kesimpulan}

Ablu al-Halli $W$ a al-'Aqdi adalah lembaga perwakilan (lembaga legislatif) dari berbagai macam unsur dalam masyarakat dan diberikan kepadanya beberapa kewenangan untuk menampung dan melaksanakan aspirasi masyarakat; mulai dari hal memilih/mengangkat pemimpin negara, membuat undang-undang sampai kepada hal mengatur urusan-urusan lain yang terkait dengan kepentingan negara dan rakyat. Dalam menetapkan sesuatu perkara, lembaga Ablu alHalli Wa al-'Aqdi, pertama, harus berdasarkan kepada ketentuan Allah SWT dan Nabi-Nya dan, kedua, berdasarkan musyawarah yang sejalan dengan ketentuan Allah SWT atau sesuai dangan jiwa/nilai/semangat Islam/syari'at. Keanggotaan Ablu al-Halli $W a$ al'Aqdi terdiri dari orang-orang yang memiliki kehebatan baik dari segi kepribadian, keagamaan maupun dari segi keahlian. Namun para ulama/ahli poltik Islam berbeda

\footnotetext{
${ }^{35}$ Ibid., h. 71.
}

\footnotetext{
${ }^{34}$ Ibid.
} 
pendapat mengenai jumlah anggota lembaga ini dalam konteks memilih/mengangkat pemimpin negara. Dengan mengkaji keberadaan Ablu al-Halli Wa al-'Aqdi sebagai lembaga perwakilan, dan selalu mengedepankan proses musyawarah dalam memutuskan semua perkara yang masuk ke dalam kewenangannnya, maka kebaradaan dan peranan lembaga Ablu al-Halli $W$ a al-'Aqdi merupakan bagian dari proses demokrasi.

\section{Daftar Pustaka}

Al-Maududi, Abu A'la, Hukum dan Konstitusi Sistem Politik Islam, diterjemahkan oleh Asep Hikmat, Bandung: Mizan, 1990.

Al-Mawardi, Imam, Al-abkam Assulthaniyyah: Hukum-bukum Penyelenggaraan Negara dalam Syariat Islam, Jakarta: Darul Falah, 2006.

Amin, Muhammad, "Pemikiran Politik Al-Mawardi," dalam Jurnal Politik Profetik, Vol. 04, No. 2, 2016: 117-136.

Budiarjo, Miriam, Dasar-Dasar Ilmu Politik, Jakarta: Gramedia Pustaka, 2008.

Cipto, Bambang, Dewan Perwakilan Rakyat Dalam Era Pemerintahan Modern Industrial, Jakarta: Rajawali Press,1995.

Dahlan, Chozin H., "Islam, Politik dan Demokrasi," dalam Jurnal Publiciana, Vol 8, No 1, 2015: 94-108.
Diana, Rashda, Siswanto Masruri, Surwandono, "Etika Politik dalam Perspektif al-Mawardi," dalam Tsaqafah, Vol. 14, No. 2, November 2018: 363-384.

Hadi, Syofyan, "Prinsip Checks and Balances dalam Struktur Lembaga Perwakilan Rakyat Di Indonesia (Studi Terhadap Usulan Perubahan Kelima UUD NKRI Tahun 1945)," dalam Jurnal Ilmu Hukum, Edisi: Januari - Juni, 2014: 4959.

Held, David, Demokrasi dan Tatanan Global dari Negara Modern bingga Pemerintahan Kosmopolitan, Yogyakarta, Pustaka Pelajar, 2004.

Huda, Ni'matul, Hukum Tata Negara Indonesia, Jakarta: PT Raja Grafindo Persada, 2010.

Ibrahim, Anis, Legislasi dalam Perspektif Demokrasi: Analisis Interaksi Politik dan Hukum dalam Proses Pembentukan Peraturan Daerah di Jawa Timur, Universitas Diponegoro: Disertasi, 2008.

Iqbal, Muhammad dan Amien Husein Nasution, Pemikiran Politik Islam, Jakarta: Prenada Media Group, 2010.

Iqbal, Muhammad, Fiqih Siyasah Kontekstualisasi Doktrin Politik Islam, Jakarta: Gaya Media Pratama, 2007.

Jindan, Khalid Ibrahim Jindan, Teori Politik Islam : Telaab Kritis Ibnu Taimiyyah tentang Pemerintahan Islam, diterjemahkan oleh Masrinin, Jakarta: Risalah Gusti,1995. 
Kholiq, Farid Abdul, Fikih Politik, Jakarta: Sinar Grafika, 2005.

Muntoha, "Demokrasi dan Negara Hukum," dalam Jurnal Hukum, No. 3, Vol. 16 Juli, 2009: 379395.

Pulungan, J. Suyuthi, Fiqh Siyasah, Jakarta: Raja Grafindo, 1997.

Sadjali, Munawir, Islam Dan Tata Negara, Jakarta: UI-Press, 1993.

Said, Gatara A.A, dan Moh. Dzulkiah Said, Sosiologi politik, Bandung: Pustaka Setia, 2007.

Suliswono Dwi, Tri Wahyuningsih, Dikdik Baegaqi Arif, Demokrasi, Yogjakarta: Program Studi Pendidikan Kerwarganegaraan, Universitas Ahmad Dahlan, 2012.

Tim ICCE UIN Jakarta, Pendidikan

Kewarganegaraan (Civic Education): Demokrasi, Hak Asasi Manusia dan Masyarakat Madani, Jakarta: Prenada Media, 2005.

Zulifan, Muhammad, "Politik Indonesia," dalam Indonesian Political Science Review, 1, 2, 2016: 171-195. 